\title{
Trade and cooperation opportunities for the MERCOSUR countries in the livestock sector and beef meat in Indonesia
}

\author{
Sebastian Sterzer*1) and Siti Azizah ${ }^{2)}$ \\ ${ }^{1)}$ Observatory of International Trade, Department of Social Sciences, National University of \\ Lujan, Campana, 2804, Argentina \\ ${ }^{2)}$ Faculty of Animal Science, Universitas Brawijaya, Indonesia
}

Submitted: 21 July 2021, Accepted: 30 July 2021

\begin{abstract}
Indonesia is the largest economy in the Southeast Asia region, with the largest population in that region as well. Therefore, each productive and industrial sector that helps the growth and development of the country and its population gets attraction. The livestock sector can be a good example of the above. In this sense, the countries that make up the Southern Common Market (MERCOSUR), that is, Argentina, Brazil, Paraguay, and Uruguay (Venezuela is suspended) can contribute to develop the livestock sector in Indonesia, looking for further cooperation and business opportunities that can also help to improve the well-being of Indonesians. The objective in this article will be to make a brief approach to the Indonesian livestock sector in general and the beef market, to understand how the MERCOSUR countries could contribute to the development of that. The results of the analysis indicate that Indonesia should develop its livestock sector using best practices that contribute to sustainable development, with support from the public sector. The use of new technologies could contribute to the improvement of the sector, and bovine genetics can contribute to a greater and better supply. It is concluded that the MERCOSUR countries have opportunities to contribute to the growth and development of the livestock sector in Indonesia, through the signing of relevant legal agreements both at the bilateral level and, in the case of MERCOSUR, acting as a bloc.
\end{abstract}

Keywords: livestock production; Consumption trade; MERCOSUR investment technology

*Corresponding Author: arioci@ mail.unlu.edu.ar 


\section{INTRODUCTION}

Indonesia has a livestock sector that encourages research to find opportunities to cooperate in its development with other countries (Soedjana and Priyanti, 2017). In this case, possible cooperation with South American countries that make up the regional bloc called the Southern Common Market (MERCOSUR) is proposed. Currently, Argentina, Brazil, Paraguay, and Uruguay are full members, while Venezuela is suspended due to the violation of one of the clauses of the bloc's regulations.

The situations in which Indonesia would need to have a greater development to be able to strengthen its sector, in all value chains, from the production stage to the commercialization. The novelty will be given by the idea that technology, the best livestock practices (in a broad sense) and sustainable development closely related to caring for the environment will be those opportunities for the MERCOSUR countries to narrow more and better ties with Indonesia, to obtain mutual benefit. Until today, imports are still one of the best alternatives to meet the needs of beef in Indonesia. Rudatin (2016), Salendu et. al. (2019), and Danasari et.al. (2020) state that a decrease in imports of feeder cattle and beef will cut the population of local beef cattle in Indonesia. Meanwhile, increasing imports of breeder cattle can rise the population of local beef cattle in Indonesia. Importing beef can give technology, social and economic benefit to Indonesia (increasing the farmers' income, creating jobs, and improving the genetic quality of beef cattle). Indonesia's livestock industry is currently dominated by small farms with low productivity because they still conduct traditional agricultural methods, poor supply chain structure, information, product, and finance flow (Subandi, 2019; Mappigau, 2017). Thus, Indonesia still needs support in improving business aspects in strengthening the competitiveness of beef cattle business. The competitiveness of beef cattle business is determined by many factors, including potential resources such as feed and cattle breeds, labor, technology, and market demand. Existing conditions indicate that the availability of agricultural waste feed and forage, cattle breeds that are adaptive to the tropical climate and relatively competitive labor wages are sources of comparative advantage in beef cattle business in Indonesia (Domestic Resources Cost/DRC $<1)$. Likewise, the influence of technology through increasing daily weight gain and crossbreeding superior cattle will have a positive impact on increasing the competitiveness of beef cattle (Rouf, 2014).

The purpose of the article is directly to find and make known to the protagonists of the MERCOSUR countries, about those opportunities in the Indonesian livestock sector that allow a better approach between the countries and offer goods and services that are adapted to demands of the sector.

\section{RESULT AND DISCUSSION Why is the livestock sector attractive? Analysing the demand}

Indonesia stands out in the Southeast Asian region for being the country with the largest population (more than 270 million inhabitants; by 2024, the population is expected to increase to 284 million, and 319 million in 2045), in addition to having a rapidly expanding middle class, manifested in the purchasing power for the home as a great economic indicator. In addition, it is a population that is digitally connected (especially young people), an economic growth that has been constant in recent years and an urbanization in marked rise. According to Create Change (2020) from the perspective of the retail side of the beef supply chain, online market now is more and more attractive to Indonesians besides they mostly buy from retailers, including fresh food markets, supermarkets, and fresh food vendors. During the COVID19 pandemic, the Indonesian government implemented a large-scale social distancing order to change the shopping behaviour of Indonesian consumers from offline to online 
transactions. The electronic commerce of agricultural products operates with a completely different business model. Although these business models are generally considered to shorten the supply chain from farm to consumer, the types of intermediaries and contractual arrangements between e-commerce platforms and other chain participants are important from one model to another. This highlights the importance of considering several business models in a study to understand online meat marketing and the meat buying behaviour of online consumers.

There will be a $180 \%$ increase in the number of households with disposable income greater than USD 35,000 in 2024 (compared to 2020). Meanwhile, for disposable income greater than USD 75,000 , the increase in households is expected to be $217 \%$ in 2024 . Clearly, it is possible to verify the great expectations that this type of information generates in the market. On the other hand, spending on groceries was IDR 7,769,544 per person in 2019 , defined as the total annual turnover of the grocery retail market in that year, divided by the population (Meat and Livestock Australia, 2020). Soedjana and Priyanti (2017) have affirmed that Indonesia, being a country that has a sustained growth in the number of middleand high-income households, represents the impulse of the demand for basic products that have high income elasticity, as well as the case of livestock products. The consumption of livestock meat presents a degree of diversification in terms of animal origin, following cultural and religious factors, preferences, for example, in terms of the taste of meat, and other reasons more related to economic income in households. The availability of beef, both imported and local, is closely related to national food security. The availability of beef is as important as the availability of rice, sugar, corn, eggs, poultry, soybeans and so on which are the most basic human needs. The need for meat and milk to meet the consumption of animal protein is closely related to the health and intelligence of the nation (Jiuhardi, 2016). In percentage terms, $75 \%$ of the $60 \mathrm{~kg}$ that make up per capita consumption in Indonesia is represented by fish consumption; then $17 \%$ is chicken consumption, $5 \%$ cow and $2 \%$ pork. The island of Java is home to $70 \%$ of all Indonesian beef consumption $(50 \%$ of the population also inhabits this island) (Meat and Livestock Australia; 2020). Despite its small relative participation in relation to other types of meat in Indonesia, beef is considered by the population as the most superior meat both for its nutritional qualities, as well as for its religious importance, including during large events. as Idul Fitri. As IPB University report (2018) that beef is the main source of animal protein and experiences big price fluctuations during the fasting month (Ramadan) and Idul Fitri celebrations. Rising beef prices in the domestic market will have a negative impact on consumers since will decrease their purchasing power. In turn, this will compel consumers to shift from buying domestic beef to alternate products (such as imported beef and/or buffalo).

In the wet markets, the cheapest meats are often bought, including Indian buffalo meat. There is a lot of price competitiveness, and sellers in that market are looking to offer the cheapest meats and, at the same time, make the biggest profits. Consumers buy beef most often in wet markets. This is due in part to the perception of freshness of the beef that is sold in the wet markets and the preferences of Indonesian consumers for hot meat and their habit of cooking with fresh ingredients bought that day. In addition to the capital Jakarta, other major urban centers for beef consumption are found in Surabaya, Bandung, and Semarang. On the other hand, most of the imported meat is sold at retail mainly in supermarkets and hypermarkets (62\% of the total imported meat), then in the wet market (20\%), butchers $(17 \%)$ and online retailers (2\%) (Asikin et al., 2020). Christie Chang et.al (2020) state that although limited to the urban, but the 
demand for higher quality beef cuts may increase due to income growth, young population with higher incomes, the tourism sector, and the expatriate people. This situation creates increasing pressure on the livestock subsector to meet the growing demand for a high-value animal protein. Consequently, the livestock subsector will grow in line with a combination of human population growth, increased income, and urbanization, as there is a strong positive relationship between increased household income and increased consumption of animal protein.

\section{Why is the livestock sector attractive? Analysing the offer}

The first thing to say is that livestock plays a key role in several aspects: growth, employment, trade, food and nutrition security, as well as poverty alleviation and gender equality. According to Soedjana and Priyanti (2017), the higher the economic development there will be a relatively lower share of agriculture in GDP. However, the interesting thing is that livestock will continue to grow due to changes in demand and the type of consumption, mostly based on animal protein. A second aspect that anyone interested in livestock farming in Indonesia should know is that animal husbandry in this country is largely dominated by traditional systems and that they are small-scale, especially located in rural areas. Soedjana and Priyanti point out that the national production of beef has been concentrated in more than $96 \%$ by small farmers, who raise between 1-3 head of cattle per household. In addition to a traditional use of husbandry techniques, another piece of information to know is that they often keep animals to save lives and market them when they need cash. This, from a certain point of view, may represent a high production cost per kilogram of live weight of cattle. Permani (2013) revealed some challenges that limit further increases in Indonesian beef cattle productivity. These challenges include limited farmer education, poor management, dry season forage shortages, high feed prices for beef cattle, limited access to bank loans, limited access to high-quality genes, and conversion of agricultural land. This will affect the quality of pasture and food resources.

Livestock feed is composed not only of forage and residues of certain crops, but also of other foods, cassava starch, rice bran, coconut flour and wheat pollock, among others, which are usually not concentrated. In a large majority, parcels of land are used both for the cultivation of what will later be said livestock feed, as well as livestock activities (Asikin et al., 2020). In the absence of a crop-livestock integration system, ruminants tend to feed in the backyards of homes, roadsides, and some forests. Consequently, productivity will be relatively low. It must be noted that $76 \%$ of small livestock producers are engaged in breeding, followed with $24 \%$ by fattening activities. In some rural households, in fact, both modalities are practiced. The authors argue that fattening systems have the highest profitability. On the contrary, there are private investors who have not been interested in raising livestock, because according to them there is a low and slow profitability. According to Widayati (2018), meat production in Indonesia in the last 30 years has been changing, from 1987 when beef and buffalo meat production was predominant, to go then to 2017 where broilers lead production. According to this author, the factors that promote shifts from one subsector to another will be based on technological changes, as well as the prices of inputs and marketing, and the patterns of consumption preferences on the part of the population.

Indonesia is a net food importer. The phenomenon of the need for food originating from meat is always increasing and currently it can only be met through imports (Rusdiana, 2019). As can be seen in the table below, even in the meat sector, Indonesia must resort to imports in order to satisfy the consumption needs of its population. According to data from the Asian Development Bank (2019), Indonesia has imported $2 \%$ of its demand for meat. 
Table 1. Food Commodity Demand, Production, and Trade, Indonesia, 2000-2015

\begin{tabular}{|c|c|c|c|c|c|c|c|c|c|c|}
\hline \multirow{2}{*}{$\begin{array}{c}\text { Food } \\
\text { Commodity } \\
\text { Group }\end{array}$} & \multicolumn{3}{|c|}{2000 (000 MT) } & \multicolumn{3}{|c|}{2015 (000 MT) } & \multicolumn{2}{|c|}{ Demand } & \multicolumn{2}{|c|}{ Production } \\
\hline & Demand & Production & Trade & Demand & Production & Trade & $\begin{array}{c}\text { Change, } \\
2000- \\
2015(\%)\end{array}$ & $\begin{array}{c}\text { Annual } \\
\text { Growth } \\
\text { Rate }(\%)\end{array}$ & $\begin{array}{c}\text { Change, } \\
2000- \\
2015(\%)\end{array}$ & $\begin{array}{l}\text { Annual } \\
\text { Growth } \\
\text { Rate }(\%)\end{array}$ \\
\hline $\begin{array}{l}\text { Meat } \\
\text { Products }\end{array}$ & 1,740 & 695 & -45 & 3,679 & 3,606 & -73 & 111 & 4.85 & 113 & 4.76 \\
\hline $\begin{array}{l}\text { Beef and } \\
\text { buffalo } \\
\text { meat }\end{array}$ & 422 & 386 & -36 & 686 & 614 & -72 & 63 & 3.83 & 59 & 3.26 \\
\hline $\begin{array}{l}\text { Sheep and } \\
\text { goat meat }\end{array}$ & 79 & 78 & -1 & 120 & 118 & -1 & 52 & 0.7 & 51 & 0.64 \\
\hline Pig meat & 414 & 413 & -1 & 783 & 779 & -4 & 89 & 4.59 & 89 & 4.54 \\
\hline $\begin{array}{l}\text { Poultry } \\
\text { meat }\end{array}$ & 832 & 818 & -14 & 2,120 & 2,119 & -1 & 155 & 5.76 & 159 & 5.79 \\
\hline Cereals & 50,731 & 44,293 & $-6,438$ & 78,897 & 70,353 & $-8,545$ & 56 & 3.47 & 59 & 3.68 \\
\hline Maize & 10935 & 9677 & -1258 & 23043 & 19612 & -3432 & 111 & 5.85 & 103 & 5.87 \\
\hline Rice & 36076 & 34616 & -1460 & 49436 & 48574 & -862 & 37 & 2.51 & 40 & 2.79 \\
\hline Wheat & 3641 & -- & -3641 & 7458 & -- & -7458 & 105 & 4.72 & -- & -- \\
\hline Fruits & 8419 & 8413 & -6 & 18342 & 17999 & -343 & 118 & 4.32 & 114 & 4.1 \\
\hline Vegetables & 7185 & 6985 & -199 & 11592 & 11347 & -245 & 61 & 3.75 & 62 & 3.72 \\
\hline Fruit Crops & 20283 & 19259 & -1025 & 30247 & 28937 & -1310 & 49 & 2.85 & 50 & 2.81 \\
\hline Soybean & 2294 & 1018 & -1276 & 2672 & 963 & -1709 & 16 & 2.58 & -5 & 1.11 \\
\hline Pulses & 324 & 291 & -33 & 322 & 245 & -77 & 0 & 0.08 & -16 & -1.51 \\
\hline $\begin{array}{l}\text { Starchy } \\
\text { Root Crops }\end{array}$ & 19652 & 19269 & -382 & 30403 & 28402 & -2001 & 55 & 3.38 & 47 & 2.77 \\
\hline Sugar & 3705 & 2190 & -1.515 & 5050 & 2521 & -2529 & 36 & 1.8 & 15 & 0.45 \\
\hline
\end{tabular}

()$=$ negative."--" = not applicable or zero value. Negative trade $=$ imports. Positive trade $=$ exports. mt - metric ton. Source: FAOSTAT (online), BPS, Statistical Yearbook of Indonesia (various years).

Some problems that small farmers face and that end up affecting finally the productivity of the sector, is related to the limitation in terms of lack of quality and quantity of forage (which is aggravated in the dry season periods, approximately between May and November), which was also aggravated because of the COVID-19 since 2020 (Trobos Livestock, 2020). The farm allows providing food sources such as grazing and crop residues but, ultimately and therefore, it must resort to importing forage. Due to these limitations, feed costs constitute around $60 \%$ of all production costs (Asikin et al., 2020).

The Meat and Livestock Australia (2020) organization forcefully asserts that beef imports represent almost $70 \%$ of total beef consumption in Indonesia (equivalent to imports of 375,000 tons), with Australia and India being the main suppliers, as can be seen in Figure 1.

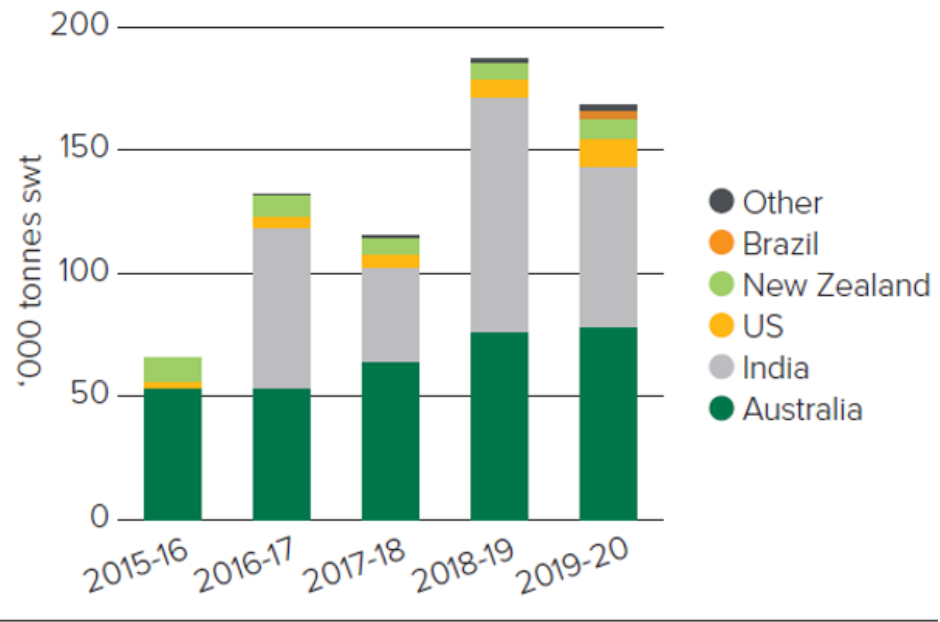

Source: IHS Markit, Australian Fiscal Year

Figure 1. Indonesia beef imports 
By the other side, what Soedjana and Priyanti highlight is that an integration program has been carried out in Indonesia to accelerate the integration system of cattle (not only cows, but also and more importantly sheep) with palm oil. The idea is that, through technologies and innovations, productive efficiency is achieved both in the oil palm farm and in the production of ruminants. What could be achieved, mainly in the islands of Sumatera like Kalimantan where there are a majority of palm plantations, is a reduction in production costs, as well as a higher population of cattle. With technology, the main aim is to optimize the use of oil palm derivatives (either naturally or as waste from its industrialization) as feed for ruminants. As stated by Handaka et al. (in Nur, et.al., 2018) that in general, the advantages of the livestock crop integration system are: 1) diversification of resource use, 2) reducing business risk, 3) efficient use of labor, 4) efficient use of production inputs, 5) reduce dependence on chemical energy, 6) environmentally friendly, 7) increase production and 8) sustainable farmer household income. At the time of oil palm replanting, cattle can be used as a promising alternative source of income. Maintenance for fattening has been able to provide family income within a period of 4-6 months, the cows can be sold by providing feed that is around the farmer's residence (Siswati, et. al., 2019).

\section{The MERCOSUR countries: a brief overview of their livestock (beef) industry and the potential for cooperation with Indonesia}

First, it should be noted that Argentina, Brazil, Paraguay, and Uruguay play a fundamental role in the international trade of beef from the Latin American region, which is responsible for $40 \%$ of that volume, according to the Inter-American Institute for Cooperation for the Agriculture (IICA) (Ganadería.com, 2020). In this region, production is focused on farmers operating on a small scale (for example, 4 and 20 animals per farmer, as in the case of
Central America). In Latin America, 50\% of the regional GDP is represented by the meat and milk sectors, so their performance is fundamental. In particular, the livestock sector has experienced exponential growth in the region of more than $30 \%$ in recent years.

MERCOSUR countries such as Argentina and Brazil are among the main countries with the highest number of cattle: in general, India is first with $34 \%$, Brazil with $24 \%$, the United States, China, and the European Union with $9 \%$ each, and then Argentina with $6 \%$. As already mentioned, the bovine complex occupies an important place in the world economy, especially in Latin America and the Caribbean, where 5 countries concentrate almost $90 \%$ of production and consumption. Brazil is the main producer and exporter in the region. Internal productivity at competitive costs, lower internal logistics costs and the ability to offer quality products within world animal health standards are the main arguments for Brazil's competitiveness in the world beef market (Ferro Moreno et al., 2021).

In the cases of Paraguay and Uruguay, the first thing to recognize is the great work they have done to export their beef. In Paraguay, beef is the second most important export product. In both countries, only approximately $20 \%$ of the meat they produce is consumed (Infobae, 2021). International competitiveness in Paraguay, evidenced by the increase in beef exports, is explained by the joint work of the public and private sectors, in addition to the genetic improvement that was introduced to increase quality and production (Ferro Moreno et al., 2021). In Uruguay, livestock activity provided more than $80 \%$ of exports for most of Uruguay's existence and even earlier. With four head of cattle per inhabitant, it is the country with the highest livestock activity in the world. However, some authors say that since the 21st century, little has been done other than implementing a highly sophisticated individual traceability system to improve the competitiveness of 
Uruguayan beef and its inclusion in the markets (Moralès et al, 2020). Differentiation and added value are of primary importance to increase the competitive advantages of Uruguayan meat in the global market, particularly when its small scale of production is a limiting factor (Montossi, Ayala and Díaz, 2008).

Some MERCOSUR countries are in a process of reordering the supply of meat both in the local market and abroad. Such is the example of Argentina, whose government ordered, through Decree No. 408/2021, the development of a National Plan to stimulate the production of beef in the country but, at the same time, a series of partial restrictions on exports of beef (Argentina.gob.ar, 2021). This is particularly important since the bovine meat agro-industrial complex is the main supplier of protein of animal origin in the Argentine market and one of the main exporters. Beef is the main source of animal protein in the Argentine market, which consumes around $80 \%$ of its production (Ferro Moreno et al., 2021). In Argentina, in many cases there was a simultaneous increase in both the sown area and the number of cattle (thanks to a more intensive management of the keeping of animals and the extension of fattening to corral) (Bona, 2021).

The MERCOSUR countries are aware that meat production is especially under observation to achieve forms of sustainable management that reduce and mitigate its environmental impact, particularly the carbon footprint. In America, specifically in the MERCOSUR countries, livestock activity has been and continues to be both an agent of interaction with ecosystems and of transformation of the environment, with varied results - good and bad - in the different scenarios known to its long history (Lopes, Moraes and Wilcox, 2020). The management of forestry-livestock systems must then be prioritized so that they can respond to the global demand for meat with a focus on sustainability in management as a purchase requirement. In the case of Argentina, since 2019 there is a Guide to
Good Livestock Practices (Agrositio, 2021). In Brazil, the company Marfrig Global Foods, leader in the production of beef and the world's largest producer of hamburgers, together with EMBRAPA, the state agricultural research company dependent on the Ministry of Agriculture of Brazil, launched the Viva brand, a new line of meats with attributes of sustainability and traceability of carbon neutral meat. This project has a certification of cattle raised in silvopastoral or agro-silvopastoral integration systems. In the case of Brazil, there are studies that seek to identify the social, economic, and environmental impacts of the specialization of livestock activity and its level of modernization (Vilela Ferreira et. Al, 2020). However, at the regional level, more information is needed in the case of semi-arid regions of greater vulnerability, where livestock farming predominates due to few diversification alternatives and constitutes an activity of great contribution to local development (Scoponi et al., 2020).

Uruguay is also making important steps in the race for the climatic balance of its livestock. In this sense, a milestone was marked with the agreement between BPU and Montes del Plata, to develop the integration between livestock and wood (Blasina, 2021). By the other side, the project "Improving the sustainability of family livestock in Uruguay" was implemented with the general objective of contributing to improve the profitability and viability of family livestock farms without affecting the natural resources (soil, water, natural resources) in which they are bases the production of meat and wool in that country. There, livestock breeding has as its main forage base the natural field (Gómez and Porcile, 2020). Perhaps, considering that Indonesia has been developing a model of productive integration between oil palm and livestock, to reduce costs and increase the number of livestock, it could be compared with the link between the forest industry in Argentina and Uruguay, with different varieties of flora, but with the same 
integrating objective regarding livestock and the search for the use of resources and cost efficiency.

An unavoidable aspect in the analysis of the livestock sector, and one that allows opportunities for cooperation between Indonesia and MERCOSUR countries, is the animal feed. In this sense, beyond continuing to export fodder for livestock, it is also possible to collaborate in the local development of crops such as corn, soybeans, sorghum, among others. Here, Argentina has already shown interest and started a path of cooperation with Indonesia (Iflah, 2019; Syafaruddin, 2017). It will then be a matter of intensifying and extending it so that the other MERCOSUR countries can also cooperate with Indonesia.

MERCOSUR countries must understand that Indonesia's smallholder livestock system is facing constraints in responding to booming domestic demand for beef. Indonesia, with more than 270 million of people is the fourth largest country in terms of population. Recent average meat consumption of 2.72 $\mathrm{kg} /$ capita/yr is projected to reach 3.36 $\mathrm{kg} / \mathrm{capita} / \mathrm{yr}$ in 2024 due to progressively growing population, income, and animal protein consumption. The increasing demand for meat has not been matched by domestic beef production, the supply of which is less than $60 \%$ of the national demand for beef (Agus and Widi, 2018). It should be noted that Indonesia lacks large open range grazing lands and is densely populated. However, bearing in mind the existence of numerous crops on Indonesian soil that could provide cheap sources of feed for livestock (both for breeding and fattening) means that the integration of crops and livestock is a possible feeding solution. In short, it is about better feed management to improve productivity.

\section{CONCLUSIONS}

Indonesia has a livestock sector that has been marked by certain limitations in terms of its production, to cope with a growing demand from the population in that country. For this reason, it resorts to meat imports from different countries, as well as live cattle. This situation allows the MERCOSUR countries (Argentina, Brazil, Paraguay and Uruguay) the opportunity to cooperate with Indonesia so that it can develop its livestock sector; in other words, not only from the perspective of being able to export meat or live cattle from South America, or investing in some way there, but also being able to share their know-how, best sustainable practices, bovine genetics, development of crops for cattle feed, among others.

Whether through a Memorandum of Understanding (MoU), a MERCOSURIndonesia Free Trade Agreement or another type of legal framework, clearly the potential that Indonesia presents in terms of economy and market, would allow MERCOSUR countries to develop cooperation and business with the Asian country and that, in turn, allows Indonesia, its livestock sector and its population in general, a better development and prosperity.

\section{REFERENCES}

Agrositio. (2021). Sistemas Forestales $Y$ Carne Carbono Neutro: El Futuro De La Ganadería Mundial. https://www .agrositio.com.ar/noticia/217413-siste mas-forestales-y-carne-carbono-neutr o-el-futuro-de-la-ganaderia-mundial

Agus, A., Widi, M., \& Satya, T. (2018). Current situation and future prospects for beef cattle production in Indonesia A review. Asian-Australasian Journal of Animal Sciences, 31(7), 976-983. https://doi.org/10.5713/ajas.18.0233

Argentina.gob.ar. (2021). Programa De Estímulo A La Cadena Bovina: Plan Ganadero Federal $Y$ Más Cortes Populares Para El Mercado Interno. https://www.argentina.gob.ar/noticias /programa-de-estimulo-la-cadena-bov ina-plan-ganadero-federal-y-mas-cort es-populares-para-el

Asian Development Bank. (2019). Policies to Support Investment Requirements 
of Indonesia's Food and Agriculture Development during 2020-2045. https://doi.org/10.22617/TCS190447-2

Asikin, Z., Baker, D., Villano, R., \& Daryanto, A. (2020). Business models and innovation in the indonesian smallholder beef value chain. Sustainability, 12(17), 7020. https://doi.org/10.3390/su12177020

Blasina, E. (2021). Cuánto Pueden Bajarse Los Gases Efecto Invernadero En La Cadena Cárnica. Montevideo Portal. https://www.montevideo.com.uy/Blas ina-y-Asociados/-Cuanto-pueden-baj arse-los-gases-efecto-invernadero-enla-cadena-carnica--uc790375

Bona, L. (2021). Tendencias recientes en los cultivos de exportación y la producción ganadera en la provincia de Buenos Aires. Una mirada desde sus regiones productivas. Ciencia, Docencia y Tecnología, 32(62 mayago), 1-39. https://doi.org/10.33255/3 262/775

Christie Chang, H.-S., Sumantri, I., Panjaitan, T., Hilmiati, N., Edriantina, R., \& Prameswari, F. (2020). Australian live cattle and beef exports to Indonesia Australasian Agribusiness Review 2020. Australasian Agribusiness Review, 24(4).

Create Change. (2020). Digital Technology Options for Indonesia's and Australia's Beef and Cattle Sector. Digital technology options for Indonesia's and Australia's beef and cattle sector: Milestone four - final report.

Danasari, I., Harianto, H., \& Falatehan, A. (2020). Dampak kebijakan impor ternak dan daging sapi terhadap populasi sapi potong lokal di Indonesia. Jurnal Ekonomi Pertanian Dan Agribisnis, 4(2), 310-322. https://doi.org/10.21776/ub.jepa.2020 .004.02.9

Fadli, C., \& Satriawan, H. (2018). Analysis of the potential integration of palm oilcattle in bireuen regency, Aceh Province. AGRARIS: Journal of
Agribusiness and Rural Development Research, 4(2), 69-80. https://doi.org/ 10.18196/agr.4262

Ganadería.com. (n.d.). La Producción Ganadera De América Y El Caribe Representa 40\% Del Comercio Internacional De Carne De Res. 2021. https://www.ganaderia.com/destacad o/la-produccion-ganadera-de-america -y-el-caribe-representa-40-del-comer cio-internacional-de-carne-de-res

Gómez, R., \& Porcile, V. (2020). Interinstitutional articulation as a strategy for family livestock farming. Agrociencia Uruguay, 24(1). https: //doi.org/10.31285/AGRO.24.336

Heriyanto, H. (2018). Thematic analysis sebagai metode menganalisa data untuk penelitian kualitatif. Anuva, 2(3), 317-324. https://doi.org/10.14 710/anuva.2.3.317-324

Iflah, T. (2019). 2nd Working Group on Agriculture Cooperation IndonesiaArgentina di Bidang Pertanian. http://balittri.litbang.pertanian.go.id/i ndex.php/berita/berita-lain/887-2ndworking-group-on-agriculture-coope ration-indonesia-argentina-di-bidangpertanian

Infobae. (2021). Paraguay: El Modelo Exitoso Para Exportar Carne Vacuna Sin Descuidar El Consumo Local. https://www.infobae.com/economia/2 021/07/02/paraguay-el-modelo-exitos o-para-exportar-carne-vacuna-sin-des cuidar-el-consumo-local/

IPB University. (2018). Market Study on Food Sector in Indonesia.

Jiuhardi. (2016). Kajian Tentang Impor Daging Sapi di Indonesia. Forum Ekonomi Fakultas Ekonomi Dan Bisnis Universitas Mulawarman, 17(2), 75-91.

Lopes, M.-A. A., Moraes, M. I., \& Wilcox, R. (2020). Introducción. ganadería en el mundo americano: algunas reflexiones sobre tecnología, consumo e intercambio. Mundo Agrario, 21(46), e129. https://doi.org/10.24 215/15155994e129 
Mappigau, P., Amar, Y., \& Tang, H. (2017). Root problem of supply chain collaborative practices and strategies to improve competitive advantage of smallholders beef cattle farming in rural areas. Kuwait Chapter of Arabian Journal of Business and Management Review, 6(11), 10-18. https://doi.org/10.12816/0040333

Meat and Livestock Australia. (2020). Market Snapshot - Beef and Sheepmeat.

Montossi, F., Ayala, W., \& Díaz, R. (2008). The Challenges of Cropping and Forestry Intensification on Grasslands Liv asslands Livestock Production Systems: The Urugua oduction Systems: The Uruguayan Case. XXI International Grassland Congress / VIII International Rangeland Congress, 5-13.

Moralès, H., Moraes, M., Torres Álvarez, M., Saravia, A., \& Tourrand, J. (2020). Livestock policy. In J.-F. Tourrand, P. Waquil, M.-C. Maraval, M. T. Sraïri, L. M. G. Duarte, \& G. V. Kozloski (Eds.), Livestock public policies in Uruguay (pp. 57-66). CIRAD. https://doi.org/10.19182/agri trop/00143

Moreno, F. S., Paturlanne, J., Mariano, R., \& Pérez, S. (2021). Desempeño exportador de carne bovina en La Pampa (Argentina): 2003-2019. Estudios Económicos, 38(77), 65-81. https://doi.org/10.52292/j.estudecon.2 021.2192

Permani, R. (2013). Determinants of relative demand for imported beef and a review of livestock self-sufficiency in Indonesia. Southeast Asian Economies, 30(3), 294. https://doi.org /10.1355/ae30-3e

Rouf, A. A., Daryanto, A., \& Fariyanti, A. (2014). Competitiveness of beef cattle farming in indonesia: domestic resources cost approach. Indonesian Bulletin of Animal and Veterinary Sciences, 24(2). https://doi.org/10.143 34/wartazoa.v24i2.1053
Rudatin, A. (2016). Analysis on Indonesia's beef import. Economic Journal of Emerging Markets, 8(1), 65-72. https://doi.org/10.20885/ejem.vol8.iss 1.art5

Rusdiana, S. (2019). Fenomena kebutuhan pangan asal daging dapat dipenuhi melalui peningkatan usaha sapi potong di petani. SOCA: Jurnal Sosial, Ekonomi Pertanian, 13(1), 61. https://doi.org/10.24843/SOCA.2019. v13.i01.p06

Salendu, A. H. S., Lumenta, I. D. R., Elly, F. H., Leke, J. R., Syarifuddin, S., \& Polakitan, D. (2020). Development strategy of sustainable beef cattle. ANIMAL PRODUCTION, 21(3), 136142. https://doi.org/10.20884/1.jap.20 19.21.3.738

Scoponi, L., Lauric, A., Casarsa, F., De Leo, G., \& Torres Carbonell, C. (2020). Intensificación sostenible de la ganadería vacuna frente al cambio climático: evaluación de innovaciones mediante análisis marginal en una región semiárida de Argentina. $X$ Congreso de Costos Del Mercosur, IX Congreso de La Asociación Uruguaya de Costos -V Congreso Latinoamericano de Costos, 1-20.

Siswati, L., Nizar, R., \& Insusanty, E. (2019). Beternak sapi: sumber pendapatan alternatif pada saat kelapa sawit replanting. Jurnal Sain Peternakan Indonesia, 14(3), 319323. https://doi.org/10.31186/jspi.id.1 4.3.319-323

Soedjana, T. D., \& Priyanti, A. (2017). Competitiveness of Indonesian Livestock Production among ASEAN Countries. Indonesian Bulletin of Animal and Veterinary Sciences, 27(1), 1-14. https://doi.org/10.14334/ wartazoa.v27i1.1411

Subandi, K., Hermawan, H., \& Aryani, A. S. (2019). Value chain analysis Indonesian animal husbandry industry. Journal of Applied Sciences, 21-28.

Syafaruddin. (2017). Delegasi RI Menghadiri Working Group on 
Agriculture Cooperation di Argentina. http://balittri.litbang.pertanian.go.id/i ndex.php/berita/berita-lain/511-deleg asi-ri-menghadiri-working-group-onagriculture-cooperation-di-argentina

Trobos Livestock. (2020). Industri Pakan Terdampak Covid-19. http://trobos livestock.com/detail-berita/2020/04/0 1/7/12858/industri-pakan-terdampakcovid19-
Vilela Ferreira, G., Miziara, F., VázquezGonzález, I., Pérez-Fra, M., \& Moreira Couto, V. (2020). Distribución espacial y productiva de la ganadería bovina: el caso de Goiás, Brasil. Tecnia, 5(1), 74-101.

Widayati, S. (2018). Perkembangan Produksi Pakan Indonesia dan Prediksi Produksi 2019. Seminar Nasional Bisnis Peternakan. 